\title{
A Muhuraida (1785): o heroismo épico do bom colono
}

The Muhuraida (1785): the good settler and his epic heroism

Thiago Gonçalves SOUZA*

Instituto Federal do Pará (IFPA)

RESUMO: Muhuraida (1785), de Henrique João Wilkens, militar português, compõe o conjunto de textos da poesia luso-brasileira setecentista. Eclipsado por títulos como O Uraguay (1769) ou o Caramuru (1781) nos estudos de história literária, o poema é tido como um dos marcos inaugurais da literatura produzida na Amazônia e tem sido objeto de estudos contemporâneos, como Treece (1993), Caldas (2007), entre outros. Neste artigo, apresentamos uma leitura crítica que busca inserir o texto em seu presente político-econômico, qual seja, o das reformas conduzidas pela Coroa portuguesa no Estado do Grão-Pará e Maranhão, no que ficou conhecido como reformismo ilustrado.

PALAVRAS-CHAVE: Muhuraida; poesia épica setecentista; poesia no Grão-Pará; Amazônia colonial.

ABSTRACT: Muhuraida (1781), by Henrique João Wilkens, portuguese soldier, takes part in the hall of luso-brasilian poetry. Hidden by others titles, as O Uraguay (1769) or Caramuru (1781) in the studies of literary History, the poem is taken as beggining of the literature produced in Amazonia and is the foccus of contemporary studies, like Treece (1993) and Caldas (2007), among others. In this article, we present a reading that inserts the text within its context, namely the reforms conducted by the portuguese Crown in State of Grão-Pará and Maranhão, in what is named Ilustrated Reformism.

KEYWORDS: Muhuraida; epic poetry (18th. Century); poetry in Grão-Pará; colonial Amazonia.

\footnotetext{
Doutor em Literatura Comparada pela Universidade do Estado do Rio de Janeiro (UERJ). Atualmente, é professor de Língua Portuguesa e Literatura no Instituto Federal de Educação, Ciência e Tecnologia do Pará (IFPA) - campus de Bragança.
} 


\section{Introdução}

O manuscrito do poema heroico Muhuraida, de autoria do português Henrique João Wilkens, data de 1785. Apenas em 1819 ganhou a primeira edição, em Portugal, pela Imprensa Régia de Lisboa, sob os cuidados do padre Cipriano Pereira Alho. No painel da nossa poesia épica setecentista, foi eclipsado por títulos como O Uraguay (1769), de Basílio da Gama, e Caramuru (1781), de Santa Rita Durão, estes dois retomados pelos intelectuais românticos, como Ferdinand Denis (1798-1890) e Gonçalves de Magalhães (1811-1882), como precursores do movimento indianista.

Somente na década de 90 do século XX a Muhuraida ganharia reedição, preparada em parceria entre a Fundação Biblioteca Nacional do Rio de Janeiro, o Governo do Amazonas e a Universidade Federal do Amazonas, reunindo, além de dois extensos estudos críticos, o fac-símile do manuscrito, a transcrição que fora proposta por Pereira Alho e uma nova. Outras reapresentações do poema têm surgido, como a dos professores Yurgel P. Caldas (2007) e Weberson Fernandes Grizoste (2017).

Na recepção crítica do texto, destaca-se o gesto de entendê-lo em sua inserção no contexto histórico e social da Amazônia da segunda metade do século XVIII e o de explicitar como, apesar desta inserção, Wilkens oferece em seu poema possibilidades de leitura que o impulsionam para além de si mesmo. São leituras "a contrapelo", que veem o poema ora como participando de um projeto identitário para a nação que se forma (CALDAS, 2007), ora como registro da resistência indígena aos desmandos da colonização (SILVA; RAMALHO, 2011). De um modo ou de outro, pretende-se "fazer justiça" ao poema, demonstrando como ele, tanto quanto O Uraguay ou o Caramuru, poderia figurar como obra de teor indianista e de relevo para a afirmação de uma identidade nacional e regional.

Partilhamos da noção de que, ao estender retroativamente vetores de leitura oitocentista ou novecentista a documentos dos séculos XVIII e anteriores, promovem-se anacronismos que levam à invisibilização desses documentos, apesar da intenção de "resgatá-los". A leitura "indianista" ou "protorregionalista" da Muhuraida retira o poema do sistema em que circulou e no interior do qual exerceu uma clara função. Desse modo, a leitura que ora propomos retoma a intenção de devolvê-lo às contingências históricas nas quais se dão seus sentidos e às quais sua forma responde: 0

Revista Moara, n. 56, vol. 2, jan-jul 2021 ISSN: 0104-0944 
elogio do desenvolvimentismo do reformismo ilustrado, que reorganizou o plano colonial para o Estado do Grão-Pará e Maranhão (à época de Wilkens, já dividido em Grão-Pará e Rio Negro, de um lado, e Maranhão e Piauí, de outro ${ }^{1}$ ).

Embasamo-nos na noção cunhada por Ivan Teixeira (1999) de "cultura em ação", com a qual o autor pretende envolver “[...] tanto as práticas político-sociais, quanto suas manifestações nas letras e nas artes em geral [...]" em uma “[...] perspectiva integradora entre discurso artístico e discurso social" (TEIXEIRA, 1999, p. 14-15). As práticas artísticas e as práticas políticas se entrelaçam na composição do tecido histórico de um dado momento: ao crítico, cabe explicitar as linhas de comunicação entre uns e outros e localizar os textos no funcionamento de seu contexto. É um trabalho que, segundo as palavras de João Adolfo Hansen, “[...] tenta inventar, de modo verossímil, a estrutura, a função, a comunicação e valores dessas letras em seu presente colonial. Para isso, pressupõe os condicionamentos materiais e institucionais da sua produção na circunstância colonial [...]" (HANSEN, 2006, p. 20).

Sob tal compreensão, nossa hipótese é a de que a Muhuraida apresenta a composição, em verso, de representações compartilhadas por todo um conjunto de discursos orientados para comporem a realidade política do reformismo ilustrado em atuação na Amazônia setecentista. Assim, cumpre função na estruturação da sociedade colonial do Grão-Pará ao associar uma representação cristianizada do heroísmo épico (tal como presente na poética setecentista) aos valores com os quais o reformismo português pretendia redefinir as relações políticas e sociais daquele tempo e lugar: o equilíbrio, a harmonia e a ordem como caminho para a modernização e a prosperidade do Império.

\footnotetext{
${ }^{1}$ Entre os séculos XVII e XVIII, os territórios ao norte da América portuguesa são organizados em unidades administrativas autônomas e distintas do Brasil: em 1621, institui-se o Estado do Maranhão; em 1654, passa a chamar-se Estado do Maranhão e Grão-Pará, refletindo a expansão portuguesa para o oeste; em 1737, a sede é transferida de São Luís para Santa Maria de Belém, no Grão-Pará; em 1751, é renomeado para Estado do Grão-Pará e Maranhão e, em 1755, já abarca as capitanias do Rio Negro e do Piauí; em 1772, divide-se, dando origem a dois Estados, ligados diretamente a Lisboa: o do Grão-Pará e Rio Negro, com sede em Belém, e o do Maranhão e Piauí, com sede em São Luís; em 1774 as duas unidades administrativas são desfeitas e integradas ao Estado do Brasil, com sede no Rio de Janeiro.
}

Revista Moara, n. 56, vol. 2, jan-jul 2021 ISSN: 0104-0944 


\title{
1 Refazer o sistema: o reformismo ilustrado na Amazônia
}

Em 1751, Francisco Xavier de Mendonça Furtado (1701-1769), ao chegar ao Estado do Grão-Pará e Maranhão para assumir o cargo de Governador e Capitão General (no qual ficará até 1759), pinta uma imagem do Estado que é de total desordem e ruína. Em carta remetida a D. Francisco Luís da Cunha Ataíde, esboça o panorama:

\begin{abstract}
Vim parar a uma terra aonde não só se não conhece o comércio, mas nem nunca ouviram estas gentes falar na mais leve máxima dele; vindo os comissários de Lisboa roubar estes moradores, eles despicam-se não lhes pagando, ou fazendo-o com gêneros falsificados e por preços exorbitantes, e com estes estabelecimentos não é muito que tenha chegado ao ponto de ser quase impossível o restabelecer-se (FURTADO in: MENDONÇA, 2005, p. 86).
\end{abstract}

Veja-se: é a ignorância das gentes o que leva à desordem econômica e, por fim, ao desequilíbrio das relações sociais, pautadas na hostilidade entre os funcionários reinóis e os moradores da colônia. Na percepção do novo Governador, tal situação estaria longe de ser pontual: era sintoma de todo um sistema pernicioso, como descreve em carta a seu irmão, Sebastião José de Carvalho e Melo (1699-1782), o futuro Marquês de Pombal:

\footnotetext{
Toda esta piedade cristã, que os nossos soberanos têm tido até agora para a extensão da fé e para salvar estas miseráveis gentes, e todo o zelo de utilizar ao Reino com as preciosas drogas destes sertões e de enriquecer aos vassalos, não só se têm baldado, mas continuando o presente sistema se perderão, como se têm perdido, e se não poderão restabelecer da máxima e total ruína a que têm chegado (FURTADO in: MENDONÇA, 2005, p. 110).
}

Seria preciso reformar todo o "presente sistema" (SILVA, 2003) e propor um modelo novo de colonização para o Grão-Pará e Maranhão: redefinir a estrutura administrativa; confrontar as ordens religiosas, em especial a Companhia de Jesus, avaliadas como responsáveis pelo obscurantismo da região e vistas como forças político-econômicas regionais rivais à própria Coroa; equacionar a questão da mão-deobra, com a retirada dos indígenas da tutela jesuítica e a inserção dos africanos escravizados; fomentar o cultivo de gêneros agrícolas, como o arroz e o algodão, e organizar o tradicional extrativismo das drogas do sertão; conduzir a definição e defesa 
do território, com a fundação de novos povoados, como o Cabo Norte (atual Amapá), ponto estratégico de defesa contra os franceses da Guiana.

Tal plano de ações liga-se ao período conhecido como reformismo pombalino, reformismo ilustrado ou reformismo luso-brasileiro, que perpassou a segunda metade do século XVIII e buscou um reaparelhamento do Estado absolutista a partir de ações políticas e econômicas que se queriam pautadas em elementos do ideário iluminista (CARDOSO \& CUNHA, 2012; NOVAIS, 1984), como racionalidade, ordem e equilíbrio, na síntese que ficou conhecida como Despotismo Esclarecido.

Segundo Novais (1984), o entendimento da Ilustração portuguesa e das reformas por ela impulsionadas passa pela consideração do "atraso econômico" e do "isolamento cultural" percebido por letrados como Luís António Verney (1713-1792) e António Ribeiro Sanches (1699-1783), ao observarem o país no quadro das nações europeias. A constatação do atraso foi a base para a formulação da política colonial setecentista, que adaptou pragmaticamente o ideário ilustrado às necessidades que se impunham: “Ajustar-se, precisamente, mobilizando o pensamento ilustrado, moderando-o, aplicando-o à conjuntura específica - eis o que procuravam os teóricos e estadistas da Ilustração luso-brasileira" (NOVAIS, 1984, p. 110).

No contexto de conduzir Portugal para junto das nações modernas, a administração colonial apareceria como fundamental na reorganização da metrópole, em especial, a relação com as colônias. Como pontuam Cardoso e Cunha (2012), a ação de Pombal tinha por intenção o estreitamento do controle da Coroa sobre seus territórios, visando incrementar a relação mercantilista, o que se daria com a defesa da figura de um Estado que conduz a vida social com uma autoridade embasada na razão laica, objetivando o progresso e a harmonia. Um bom exemplo dessa representação está na lei de 18 de agosto de 1769, conhecida como a "lei da boa razão". A "boa razão", entre outras funcionalidades, está no cerne de leis que

[...] as [...] nações cristãs têm promulgado com manifestas utilidades do sossego público, do estabelecimento da reputação, e do aumento dos cabedais dos Povos, que com a disciplina destas sábias e proveitosas leis, vivem à sombra dos Tronos e debaixo dos auspícios dos seus respectivos Monarcas e principais Soberanos [...] (UNL, s.d., p. 5).

O arranjo do despotismo esclarecido é claro no documento: o Soberano acolhe em seu Trono as "sábias e proveitosas leis" das quais emana a disciplina necessária ao 
"sossego público". Cabe ao Povo a obediência, não pelo temor do exercício da arbitrariedade régia, mas pela compreensão de que as leis são reflexos da razão e, como tal, do equilíbrio e da ordem.

As reformas foram intensas na cultura acadêmica portuguesa, já que os jesuítas teriam ali cultivado seu obscurantismo e o transmitido de lá a todo o corpo social. No Compêndio histórico do estado da Universidade de Coimbra no tempo da invasão dos denominados jesuítas (1771), de autoria do próprio Marquês de Pombal e documento base para a reforma dos estatutos da Universidade de Coimbra de 1772, afirma-se:

\footnotetext{
Já não há, por felicidade nossa, neste presente tempo, quem possa duvidar com alguma aparência de razão de que todos os estragos, que no Moral e no Físico desta Monarquia se viram no meio dela amontoados pelo longo período dos últimos dois séculos, foram horrorosos efeitos das façanhosas atrocidades dos denominados Jesuítas (POMBAL, 2008, p. 107).
}

As relações socioeconômicas também foram redesenhadas com atos que neutralizavam a aristocracia eclesiástica (com a expulsão de sua força hegemônica, os jesuítas, dos territórios portugueses, em 1759; ou com a lei de 1774, que atingiu o Santo Ofício e o submeteu diretamente ao poder do Estado) e setores da alta nobreza (sendo emblemática a condução, por Sebastião José de Carvalho, do julgamento e execução pública de membros da família Távora, em 1759, acusados de tentativa de regicídio). Concomitantemente ao cerceamento desses poderes, buscou-se redefinir o papel da burguesia portuguesa, conferindo-lhe maior participação e liberdade de movimentação na estrutura social: pôs-se fim à distinção entre cristãos-velhos e cristãos-novos, em 1773, e desenvolveu-se uma política de incentivo a uma indústria nacional, com apoio a grandes comerciantes e novos-ricos que não vinham das famílias aristocratas. Em suma, o poder real tornava-se centro efetivo da organização da sociedade, neutralizando possíveis "rivais" e garantindo aliados leais. Maxwell frisa que as ações do Marquês se desenrolam em um momento de "[...] coincidência do Iluminismo com a luta de um antigo poder para se tornar hegemônico outra vez [...]” (MAXWELL, 1996, p. 168).

No contexto do Grão-Pará e Maranhão, também será necessário envidar esforços para tornar hegemônico o poder real. No início dos anos de 1750, Francisco Xavier de Mendonça Furtado, afinadíssimo com o discurso de Carvalho e Melo, identifica as ordens religiosas, em especial a dos jesuítas, como responsáveis pela ruína do Estado:

Revista Moara, n. 56, vol. 2, jan-jul 2021 ISSN: 0104-0944 
Como os Regulares se viram senhores absolutos desta gente e das suas povoações; como se foram fazendo senhores das maiores e melhores fazendas deste Estado, vieram a absorver naturalmente todo o comércio, assim dos sertões como o particular desta cidade, e vieram a cair os direitos reais e dízimos, e em consequência a cair o Estado, sem remissão (FURTADO in: MENDONÇA, 2005, p. 119).

Em 1759, como já mencionamos, ocorre o ato de expulsão da Companhia de Jesus dos territórios portugueses. Tirar de cena os jesuítas era essencial para o poder absolutista: eles haviam ocupado de modo bastante sólido a vida social e econômica, enquanto administradores da mão-de-obra indígena local, enquanto empresários prósperos, com suas fazendas, e também na cultura, como principais responsáveis pelo ensino e, portanto, pela formação do quadro administrativo. Portanto, era crucial garantir, contra o poder eclesiástico, o papel da Coroa enquanto núcleo organizador das relações políticas e econômicas da região.

É nessa dinâmica de luta intestina pelo poder que se inserem alguns marcos da política pombalina para o Grão-Pará e Maranhão. Por exemplo, a lei de 7 de junho de 1755 instaurou o Diretório dos Índios, retirando dos jesuítas o poder administrativo e de uso da mão-de-obra indígena e das aldeias, transferindo tais atribuições ao Estado, representado pelos diretores, e garantindo a incorporação dos indígenas aldeados na sociedade colonial, como trabalhadores livres e súditos de Sua Majestade. No mesmo ano, cria-se a Companhia Geral de Comércio do Grão-Pará e Maranhão, empresa monopolista regida pelo Estado, com a participação de capitais da burguesia metropolitana e de comerciantes locais.

Vale ressaltar ainda o quadro de grandes transformações no cenário econômico global do Império português. Como aponta Souza Júnior (2012), diante de fatores como a perda de territórios na Ásia, a queda no valor do açúcar nordestino brasileiro ante a concorrência holandesa e a diminuição do rendimento das Minas Gerais, o Grão-Pará e Maranhão aparece nos planos de D. José I como uma nova fonte de riquezas. As reformas otimizariam o rendimento econômico desses sertões que, por muito tempo, passaram ao largo do interesse metropolitano, e reforçariam a dimensão de "vasta empresa comercial" que sempre caracterizou a colonização, como pontua Caio Prado Jr. (2011).

As ações reformistas agiriam, então, no sentido de recuperar um cenário em que, de acordo com Mendonça Furtado, "tudo é confusão e desordem" (FURTADO, in: 
MENONÇA, 2005, p. 122). Como observa Ivan Teixeira, esses esforços têm em seu horizonte uma imagem de Estado, na qual este

[...] se compara [...] a uma máquina, cujas rodas e engrenagens deveriam ajustar-se adequadamente umas às outras. Nesse desenho, o governante assume função de contramestre, de cuja alma deveria fluir toda a energia necessária ao bom funcionamento do mecanismo. O rei fica de fora, supervisionando as manobras do operador sobre a máquina. [...] O bem-estar coletivo e a felicidade geral do povo encarnam os fins inalienáveis para os quais se orientam os princípios universais da razão, fundamento central dessa ideia de governo, que tanto podia se realizar com uma constituição ou sem ela, pois a suposta eficiência administrativa superava as preocupações com a forma de governo [...] (TEIXEIRA, 1999, p. 28).

Como vimos, o reformismo setecentista passava por reorganizar o sistema colonial a partir da centralização do poder administrativo nas mãos do monarca e seus representantes, os funcionários. Estes, utilizando-se da "boa razão" (e da natural ordem e equilíbrio que estariam em seu bojo), conduziriam as relações sociais, políticas e econômicas a um estado de harmonia que redundaria em ordem, progresso e prosperidade. Para o Estado do Grão-Pará e Maranhão, o reformismo ilustrado significou uma reorientação da exploração comercial da colônia, assim como uma profunda reapresentação do poder político, assentado agora plenamente na figura do Soberano, como centro irradiador da ordem e do equilíbrio que promoverá a transformação das potencialidades da região em efetivo enriquecimento geral.

\section{A Muhuraida: o heroísmo cristão e o sucesso da colonização}

Como observa Hansen (2008), o gênero épico encontrou, no século XVIII, seu derradeiro ocaso. A cultura capitalista burguesa declara a falência dos valores que, desde a Antiguidade, embasavam a epopeia: “[...] o heroísmo é improvável e inverossímil quando o dinheiro é o equivalente universal de todos os valores" (HANSEN, 2008, p. 18). Porém, antes disso, "[e]nquanto duraram as instituições do mundo antigo, a epopeia narrou a ação heroica de tipos ilustres, fundamentando-a em princípios absolutos, força guerreira, soberania jurídico-religiosa, virtude fecunda" (HANSEN, 2008, p. 17).

Revista Moara, n. 56, vol. 2, jan-jul 2021 ISSN: 0104-0944 
Elemento distintivo principal do gênero épico foi o ato heroico, com o qual o herói alcançava a dignidade de ser rememorado pelo canto do poeta: o efeito do épico liga-se à "admiração das res gestae, 'coisas feitas', que efetuam o kleos ou a fama [...]" (HANSEN, 2008, p. 27). As três obras antigas modelares do gênero - a Ilíada, a Odisseia e a Eneida, fazem justamente o elogio das "coisas feitas" por seus heróis: Aquiles, Odisseu e Enéas.

A poética do século XVIII conserva os valores do heroísmo como cerne do gênero épico, somando a estes a lição horaciana da dimensão utilitária da poesia, de modo que o heroísmo se qualifica pela ação moralmente exemplar. Francisco José Freire, na Arte Poética (1749), define a epopeia como “[...] imitaçaõ de huma acçaõ heroica, perfeita, e de justa grandeza [...], que cause huma singular admiraçaõ, e prazer, e ao mesmo tempo excite os animos a amar as virtudes, e as grandes emprezas" (FREIRE, 1748, p. 300). A ação heroica, por sua vez, é “[...] aquella acçaõ, que sendo feita por hum homem mortal, parece, que está fora da possibilidade do homem" (FREIRE, 1748, p. 302). Segundo Freire, o maravilhoso (a participação das divindades) atua como necessária ficção que garante a verossimilhança da representação de tão altas virtudes praticadas por meros homens, uma vez que “[o] homem por si só naõ he capaz de subir a hum gráo taõ eminente de virtudes [...]” (FREIRE, 1748, p. 302).

Porém, as ações heroicas, ainda que distantes das possibilidades da natureza dos homens, de comum corrupta, inspiram que eles se elevem acima da "fereza": "Aristóteles oppoem esta virtude [a heroica] ao vicio da fereza; porque assim como o homem, que naõ tem humanidade, se parece com as féras, assim o que he dotado da virtude heroica quase se exime da mortalidade [...]" (FREIRE, 1748, p. 302). A ação heroica é, portanto, a representação extraordinariamente elevada das virtudes humanas. Trata-se da virtude que é, a um só tempo, ideal e verdadeiramente humana, modelar, para que se transcenda o animalesco no sentido da humanidade plena.

Por isso o herói, para Freire, deve ser, acima de tudo, um exemplo: "Deve o Poeta Epico formar os costumes do seu Heroe todos raros, sublimes, e admiraveis [...]. Há de ser ornado de huma bondade naõ só poetica, mas também moral; porque de outro modo ficará sendo hum exemplar indigno de se imitar" (FREIRE, 1748, 311). Para o autor, o heroísmo, como síntese de prudência, generosidade e força, se expressa 
preferencialmente na guerra e, por isso, "[...] os assuntos das Epopeias perfeitas saõ de guerras, e todos os seus Heroes militares, e guerreiros" (FREIRE, 1748, p. 311).

Francisco de Pina e Melo (1695-1773), no prólogo a seu poema “épicopolêmico" Triumpho da Religião (1756), retoma a noção de que a poesia "[...] naõ se dirige só ao deleite; mas tem outro objeto mais sublime, que hé o da instrucçaõ dos homens" (MELO, 1756, p. X) e identifica o "impulso pathetico" como cerne da força educativa/persuasiva do poema, o que o torna superior à lição dos historiadores:

\begin{abstract}
Quando leio em Joaõ de Barros a historia da India, confesso que fico ensinado: mas quando recito o seu descobrimento nas Lusiadas naõ só fico ensinado, mas comovido.

Com os olhos neste impulso pathetico hé que Sophocles representa com tanta vivacidade o castigo de Egisto depois de haver gozado tantos anos das suas maldades; e assim nos persuade que o delicto sempre tem sobre si a Justiça divina [...] (MELO, 1756, p. X).
\end{abstract}

Pina e Melo, entretanto, polemiza acerca do caráter bélico da representação épica, o que lhe serve, aliás, para justificar o argumento desenvolvido em seu próprio poema: a jornada do Peregrino e seus embates teológicos com ateus, politeístas, teístas, muçulmanos, judeus, protestantes, junto aos quais quer promover o triunfo da doutrina católica. $\mathrm{O}$ autor se vale da moral cristã para redefinir o heroísmo:

[...] sendo pela commua aceitação a Fabula da Epica huma acçaõ heroica, he dar a entender que o Heroismo se limita ao espirito da guerra, quando esta, aliás, he dos maiores males, que introduzio no Mundo a miséria do pecado. Sempre entendi que o Heroismo tinha outras acçoens mais brilhantes, justas, e louváveis, em que se desempenha o seu admirável Caracter. Triste coiza seria se todas as outras virtudes, que naõ fossem as guerreiras, cahissem na desgraça de naõ serem dignas daquele aplauso, e daquele exemplo, que se póde conseguir entre os melhores esforços da eloquencia (MELO, 1756, p. XXXI).

No Triumpho da Religião, Pina e Melo procura exercitar, na reflexão e na prática poética, a ideia de uma epopeia cristã, fundamentando o gênero na "ethica sagrada":

Eu estou no conceito de que o verdadeiro Heroe he o que sabe vencer as suas proprias paixoens, e naõ destruir os indivíduos da sua mesma especie. Se Homero, e Virgilio naõ alcançaraõ este Heroismo, assim como naõ devemos seguir a introdução das suas Deidades gentílicas, também devemos melhorar de pensamentos.

Todas as acçoens sublimes, que estaõ dentro da Ethica Sagrada, saõ muito mais beneméritas da Epopeia, que as que se cantaraõ na Odyssea, na Iliada, e na Eneida (MELO, 1756, p. XXXII).

Revista Moara, n. 56, vol. 2, jan-jul 2021 ISSN: 0104-0944 
Pina e Melo expande a proposta de Freire, a de que o herói deve ser dotado principalmente de uma "bondade moral" que qualifique seus atos heroicos como modelos dignos. Mas não recusa inteiramente os feitos bélicos como possibilidade de assunto épico, mesmo porque, alguns anos depois, em 1759, publicará A Conquista de Goa, por Affonso de Albuquerque. Também nesta obra, o poeta apresenta outras reflexões sobre o gênero épico, nas quais se encontra o entendimento de que o gênero deve se ligar à vida social, recobrindo os interesses da nação, da religião e da humanidade:

\begin{abstract}
Une-se o interesse da Nação, porque os dois Poemas de Homero trataõ das acçoens dos Principes Gregos; Une-se o interesse da Religiaõ; porque toda a Theologia dos Idolatras se tirou destas duas Epopeias; Une-se o interesse da humanidade, porque a Iliada está fundada em huma paixaõ, qual foi a cólera de Achilles; e o Odyssea nas desgraças, e trabalhos Ulysses, e o modo com que os venceu e sua paciência, e sabedoria (MELO, 1759, p. 13).
\end{abstract}

Uma vez mais, retoma-se a noção de que, na epopeia, devem ser apresentados exemplos de condutas para a admiração e imitação pelos homens. Mas Pina e Melo, na melhor tradição da Querela entre Antigos e Modernos, enfatiza que os antigos precisam ser criticados no modo com que pintam seus heróis, e os modernos devem ter em vista exemplos que sejam verdadeiramente virtuosos:

Homero se contradiz nos seus dois Poemas, e he um reparo, que ainda naõ vi em algum dos seus Expositores. Na Iliada constitue a virtude na ferocidade, despenho, cólera, e inexorabilidade de Achillles; Na Odyssea a descreve na sagacidade, e tolerância de Ulysses. A Virtude, e o acerto naõ tem se naõ hum caminho. Quem a procura por dois atalhos há de vir a dar em hum monte solitário, sem alguma sahida.

Tambem se deve advertir que o fim principal das Epopeias he propornos acçoens sublimes, maravilhosas, e exemplares para delas fazermos huma boa imitação [...] (MELO, 1759, p. 14).

Tanto para Freire quanto para Melo (e, de modo geral, para a poética setecentista, que absorveu amplamente a poética horaciana), a poesia reúne o gosto estético a uma pedagogia moral. Ela atua junto à sociedade em todos os seus níveis, propondo modelos para as virtudes, a serem cultivadas pelos membros da comunidade política. Desse modo, age como instrumento por meio do qual a vida social é regulada: retomando a imagem usada por Teixeira (1999, p. 28), a do Estado como máquina, a 
poesia forneceria um caminho para mostrar o funcionamento ideal das engrenagens, para que os indivíduos regulassem seus atos, visando o bem-estar do corpo político como um todo.

No Estado do Grão-Pará e Maranhão, a dinâmica não seria diferente. Nele, o poema de inspiração épica age consolidando representações éticas necessárias às ações da administração colonial. Essa é a função que a Muhuraida, ou o Triunfo da Fé (1785) desempenha, ao pintar um quadro ideal das relações sociais entre indígenas e colonos.

Em seis cantos e pouco mais de mil versos, Wilkens toma como argumento o aldeamento do grupo indígena Mura, famoso por sua atitude hostil aos colonos na área entre o Grão-Pará, o Rio Negro e o Mato Grosso. A partir disso, elabora no poema uma imagem do "gentio feroz" e uma imagem do poder, o qual se reparte entre o diretor Matias Fernandes (responsável pela aldeia em que os Muras seriam assentados), o tenente João Batista Martel, João Pereira Caldas (então Governador da província do Mato Grosso e ex-Governador Geral do Estado do Grão-Pará e Maranhão) e, perpassando todos os demais, a Divina Providência. Da tensão entre essas forças - o "gentio" e o poder colonial - propõe-se a unidade entre elas e a conquista dessa unidade é o cerne do feito memorável cantado pelo poema.

O papel da Providência como fundamento da ação heroica é dado claramente já na proposição do poema: "Canto o Sucesso, que faz celebrado/ Tudo o que a Providência tem disposto [...] (WILKENS, 2017, p. 11). Portanto, a narrativa desenvolverá a atuação do poder divino no resgate dos muras da gentilidade, por intermédio do Anjo, de Matias Fernandes e de João Batista Martel.

Wilkens produz um poema que nitidamente se inscreve no projeto da epopeia cristã, muito próximo do que fora apresentado por Francisco de Pina e Melo. Como observado pela recepção crítica da Muhuraida, nela se observa a ausência total do feito bélico, o que poderia lançar dúvida sobre seu caráter épico ou "enfraquecer" o estatuto do herói (SILVA; RAMALHO, 2011, p. 23). Na raiz de tal configuração, Caldas identifica o que seria uma característica da poesia épica brasileira setecentista:

Mais estrategista que guerreiro, dado que seu discurso possui força maior que o hábil uso da própria arma na luta contra o inimigo; mais diplomata que militar, porque sabe o valor de negociar posições com o adversário; ligado direta ou indiretamente à administração colonial; o herói da épica brasileira do século XVIII é um conquistador civil que muitas vezes, para conseguir

Revista Moara, n. 56, vol. 2, jan-jul 2021 ISSN: 0104-0944 
seus intentos, recusa o confronto armado, preferindo utilizar seu poder de persuasão por meio da arte do discurso (CALDAS, 2007, p. 63).

Se retomamos o Uraguay ou o Caramuru, vemos, entretanto, que nenhum de seus heróis - Gomes Freire ou Diogo Álvares - se exime de pegar em armas para fazer valer a vontade superior que representam, o que torna problemática a observação de Caldas. Desse modo, a opção de Wilkens não é nem "falta" do poema, nem transformação "estrutural" peculiar ao exercício do gênero épico na colônia: a representação de uma ação heroica de caráter não militarizado já estava prevista pelo debate setecentista sobre o próprio gênero, em sua adequação à moral cristã, como vimos em Pina e Melo, que legou um exemplo desse tipo de heroísmo. A Muhuraida configura uma determinada compreensão acerca do que seja o acontecimento épico no mundo cristão: vê a ação pacífica dos funcionários João Pereira Caldas, Matias Fernandes e João Batista Martel, como verdadeiro exemplo de como se devem guiar harmonicamente as relações sociais.

Dos muras, o poema diz viverem do "corço", assaltando embarcações nos rios e saqueando povoamentos. Tópica colonial acerca dos indígenas que se mostravam hostis aos europeus, foram vistos como habitantes "[d]as densas trevas da gentilidade,/sem Templo, Culto ou Rito permanente;/ Parece, da noção da Divindade,/ alheios vivem, dela independente [...]" (WILKENS, 2017, p. 14). Nem conversão, nem comércio, nem aliança foram possíveis junto a eles, e os colonos viam "[a]ssim perdida já toda esperança/ De sossego; de Paz, ou de Amizade" (WILKENS, 2017, p. 21).

Vemos uma contradição irremediável entre estes indígenas e a colonização. Para Wilkens, apenas o milagre transformaria essa relação há tempos tensionada: eis o lugar do maravilhoso cristão em seu poema, já ativado no Canto I. A figura do Mensageiro celeste, ou Paraninfo, aparece a um jovem mura e revela a este a piedade do Criador para com todas as suas criaturas (um episódio de exposição de temas catequéticos, tão recorrente em nossa escritura colonial, de Anchieta a Santa Rita Durão).

Wilkens não se detém na elaboração da metafísica dos dogmas católicos. Encurta a mensagem do Paraninfo para anunciar aos indígenas que eles, apesar de sua ferocidade, foram convidados a juntar-se ao Rebanho de Cristo, “[...] Povo amado, [que] Na unidade da Fé; Da Caridade/ um Corpo constitui, que aterrado/ Tem o poder das 
Trevas, da maldade [...]" (WILKENS, 2017, p. 28). Para convencer o mura dos benefícios de juntar-se a tal rebanho, o Paraninfo concede um vislumbre do futuro:

IX

Tereis nos Povos vossos numerosos

Abundantes colheitas sazonadas,

Vereis nos Portos vossos vantajosos

Comércios florescer, e procuradas

Serão as Armas vossas: Poderosos

Enfim sereis, Amada, invejadas,

Serão vossas venturas; finalmente,

Podereis felizes ser eternamente (WILKENS, 2017, p. 28-29).

Nessa visão, o Anjo ressalta a prosperidade material do povo cristão: colheitas, comércio florescente, de que já gozam os aldeados de S. Antonio de Imaripi, administrada por Fernades. O jovem mura retorna aos seus, levando a boa nova: "Levantai-vos! Parentes meus amados!/ Despertai, de letargo tão profundo! Olhai, que para empresa sois chamados,/ Que Nome vos dará, já em todo o Mundo" (WILKENS, 2017, p. 30). Para convencê-los, contrasta a incerteza da vida selvagem com a segurança e o bom senso das atividades regulares e civilizadas de agricultura e pesca voltadas para o comércio. Nesta altura, o Canto III do poema, Wilkens emula o personagem camoniano do Velho do Restelo. Na fala do Ancião, a lembrança das violências perpetradas pelos brancos:

\section{XVII}

Já não lembra o agravo, a falsidade, Que contra nós os Brancos maquinaram? Os Autores não foram da crueldade? Eles, que aos infelizes a ensinaram? Debaixo de pretextos de Amizade, Alguns matando, outros manietaram, Levando-os para um triste Cativeiro, Sorte a mais infeliz, mal verdadeiro.

\section{XVIII}

Grilhões, Ferros, Algemas, Gargalheira, Açoites, Fomes, Desamparo, e Morte, Da ingratidão foi sempre a derradeira Retribuição, que teve a nossa sorte. [...] (WILKENS, 2017, p. 32)

De fato, o poema não aprofunda a tensão da passagem, mas isso não se dá pela "desconsideração" de seu potencial crítico na esteira da "atmosfera persuasiva e 
milagrosa que o poema manifesta” (CALDAS, 2007, p. 26-27). Em nota de rodapé, Wilkens adverte que a fala é alusão "[...] ao tempo, em que os Moradores do Estado do Pará, e Maranhão licença tinham, e usavam de comprar Índios escravos, daquelas Nações, que em justa Guerra e outras, cativam, e destinados eram a servir de Alimento aos Vencedores [...]" (WILKENS, 2017, p. 32). É nítida a clivagem: tempo houve em que se usou da violência; o tempo presente se usa da persuasão pela verdade e pelo bom-senso, ou pela "boa razão".

Tendo usado da violência e do roubo para com os indígenas mura, os colonos levaram os indígenas mura a adotarem a violência e o roubo. Porém, o sistema da colonização foi reformulado e tem por base a caridade e o trabalho como fundamentos da coesão de um corpo comunitário cristão ${ }^{2}$, o que traz os benefícios da civilização: paz social e econômica. É o que se põe na fala de Matias Fernandes, ao receber os muras:

XI

Eu sei, que agravos tendes na lembrança, Feitos por que, só enganos meditava, Nos Homens, como em Tempos, há mudança;

A ofensa, o Sangue derramado lava. Desafrontado o Mura agora alcança A Paz, que ele; que o Rei; que eu desejava. Sereis nossos Irmãos; Filhos da Igreja; Concidadãos, Amigos; do Orbe inveja. (WILKENS, 2017, p. 37)

A clivagem temporal elaborada por Wilkens é análoga à proposta por Mendonça Furtado, que vimos anteriormente. Para ambos, o projeto colonial demandava mudanças, a fim de que fosse possível reequilibrar o que se encontrava em desequilíbrio. Esta é a ação heroica que o Estado demanda, e não mais conflitos violentos. Na Muhuraida, a ação heroica é a conversão do indígena, com a qual é retirado das trevas da barbárie e integrado à sociedade produtiva e equilibrada da colonização. Heróis são os funcionários que conduzem tal integração, amparados pelo Anjo e pela Providência.

É no canto IV que se dá a ida dos muras para a aldeia de Matias Fernandes, guiados pelo Anjo Tutelar. O processo de conversão ao catolicismo é iniciado pelo

\footnotetext{
${ }^{2}$ Vale observar que, sem dúvida, a atmosfera cristã do poema se liga ao contexto imediato do reinado de D. Maria I, a Piedosa, que assumiu a Coroa em 1777. Maria I reabilitou amplamente os poderes eclesiásticos, na "viradeira" do que fora encaminhado por Pombal. Porém, é importante ter em vista que nenhum dos "heróis" propostos por Wilkens é, efetivamente, um eclesiástico, mas sim funcionários laicos do Estado e militares.
} 
próprio Fernandes, que os conduz por rio à vila de Ega, onde se encontram todos com o Tenente João Batista Martel, responsável, na área, pelo trabalho de demarcação de fronteiras entre as coroas portuguesa e espanhola. A integração se faz com sucesso: "Já passa o Dia; passa a Noite; a Sesta,/ Sem temor, sem receio, o Mura amigo;/ Com os Aldeanos dança já na Festa,/ Em Choupana qualquer encontra abrigo" (WILKENS, 2017, p. 45).

Os muras encontram nas vilas o exemplo da caridade e do trabalho. Fernandes conduz, de maneira precisa e enérgica, o preparo do sítio para os recém-chegados, coordenando harmoniosamente os indígenas e os demais colonos nas tarefas. É um trecho que se tem nítido registro epidíctico votado ao bom funcionário da colonização:

\section{XIV}

[...] cuida o bom Fernandes no interino

Reparo da Colônia, repartindo

$\mathrm{O}$ corte das Madeiras; do inquilino

Mura ajudado, e de Índios se servindo

Do mesmo Povo seu, com tal presteza,

Que inveja causa à Arte, à Natureza.

\section{$\mathrm{XV}$}

Não lhe esquece o preciso, útil cuidado,

De prover a futura subsistência;

Em grande roça antecipado

Meio seguro, certa providência.

Maniva, Milho, Frutas já plantado

O Mura vê, na nova residência,

Esteios uns levantam; Outros, palha

Conduzem, tecem, tudo enfim trabalha (WILKENS, 2017, p. 47).

No Canto VI, o último do poema de Wilkens, uma pequena tensão é inserida: o Diabo tenta desviar os muras do caminho da civilização, provocando sonhos de uma possível traição dos brancos, que estariam tramando uma nova escravização. Entretanto, o engodo não demora a se desfazer: o Anjo Tutelar devolve a serenidade e a resolução aos muras, fazendo com que a narrativa retorne a seu eixo. Na vila, eles são batizados por João Batista, o militar. O epílogo encerra o poema com a certeza do sucesso: "Os frutos [os muras] já colhem da Aliança./ Apesar dos acasos no concurso./ Sempre os progressos a Cantar disposto/ Aqui suspendo a voz; a Lira encosto" (WILKENS, 2017, p. 56).

A situação de enunciação poética é clara nestes últimos versos do poema: o poeta tomou a Lira e ergueu sua voz para cantar os progressos que se levantam no 
horizonte, advindos dessa nova aliança. A Muhuraida, portanto, localiza-se no cerne de uma ideologia desenvolvimentista, que alimenta o reformismo ilustrado e suas ações na região.

O estudo de Treece (1993) havia inserido a Muhuraida no contexto pombalino de estabelecer "[...] o que se pode denominar primeiro projeto agrícola protocapitalista [...]” (TREECE, 1993, p. 14) no Grão-Pará e Maranhão. As relações entre o empreendimento comercial, a política indigenista e o papel do missionarismo são considerados pelo estudioso como os fatores que alicerçam a construção do poema.

Segundo o autor, o texto reverbera a ideologia do desenvolvimentismo econômico inserido na região pelo estabelecimento da ordem capitalista colonial pelos portugueses, a qual demandava a integração do indígena como força que a impulsionará. Havia, então, a necessidade de superar a "bestialidade" identificada nos indígenas, o que se dará por meio da operação do milagre, mediada pelo Anjo e pelos funcionários. A Muhuraida opera uma tentativa de conciliar o empreendimento capitalista - a exploração econômica - com o vocabulário dos valores morais cristãos, alicerçando aquele sobre este e, ainda, legitimando o modelo pombalino da "assimilação", diante das tentativas de retomada da prática anterior de Guerra Justa.

Nesse sentido, mostram-se problemáticas as leituras que tentam ver na Muhuraida ambiguidades entre um tempo da colonização e a projeção da independência, "típicas" da poesia luso-brasileira setecentista e que alimentariam o nativismo romântico posterior: em tal chave, os muras de Wilkens guardariam uma imagem da resistência e da afirmação de uma identidade regional amazônica. Porém, valem para a Muhuraida as observações de Teixeira (1999) sobre O Uraguay: "[...] é uma narrativa sobre os portugueses em sua colônia, e não sobre os índios no Brasil [...]”, (TEIXEIRA, 1999, p. 490).

De fato, a Muhuraida ressalta o valor dos funcionários coloniais ao desempenharem seu papel de bons condutores das relações sociais no território: devem saber conduzir as gentes com as virtudes cristãs, de modo ordenado, a fim de promoverem o progresso. Trata-se mesmo da glorificação de um processo "civilizatório".

Não caberia a um poeta do tempo exaltar a rebelião. A poesia do tempo desconhecia a tópica da revolta do indivíduo contra o Estado. Ao incorporar o

Revista Moara, n. 56, vol. 2, jan-jul 2021 ISSN: 0104-0944 
índio, o poema o encara como componente adverso à ação central da fábula, e não como símbolo de superioridade brasílica ou rebeldia separatista. [...] Pombal sempre fez questão de divulgar a ideia de que sua política, contrariamente ao que faziam os jesuítas, se orientava no sentido de incorporar os índios brasileiros ao organismo social português, como deixa claro a segunda nota de Basílio ao texto de O Uraguay (TEIXEIRA, 1999, p. 491).

As palavras são quase exatas para a Muhuraida. O poema trata da integração do indígena à sociedade portuguesa, ideada, no poema, pela combinação da catequese católica e da prosperidade econômica. A fala crítica do velho mura à violência colonial é uma imagem do "componente adverso" que esteve presente no passado da relação entre portugueses e muras, mas que o processo civilizatório regido pelo Estado reformado teria resolvido no presente de Wilkens. Considerando que os efeitos cantados pelo poeta são advindos das bases lançadas por Pombal, abre-se a perspectiva de entendermos a Muhuraida como poema inscrito no universo da louvação pombalina, o que o alinha à produção setecentista brasileira não pelo viés do "pré-romantismo", mas pela participação, assim como o fazem O Uraguay e o Caramuru, na realidade ideológica do século XVIII luso-brasileiro.

\section{Considerações finais}

Em janeiro de 2020, o presidente Jair Bolsonaro afirmou: “O índio mudou, tá evol[uindo]... Cada vez mais, o índio é um ser humano igual a nós. Então, vamos fazer com que o índio se integre à sociedade [...]" (UOL, 2020). O pressuposto desta fala é: o indígena está fora da "nossa" sociedade e está abaixo da humanidade que compõe esta sociedade. Por isso, é preciso promover a "evolução" do índio e, então, integrá-lo.

Em 1785, há 215 anos, Henrique João Wilkens compunha a Muhuraida tendo por base os mesmos pressupostos, a serviço do colonialismo português. A que colonialismo a fala de Bolsonaro serve? Agronegócio, mineração e outras indústrias têm, entre si e a floresta, os territórios indígenas. Por isso o discurso atual da "assimilação" reaparece, fortalecido por um novo velho imperativo de exploração econômica da Amazônia, revestido com o dourado do discurso do "desenvolvimento" e do "enriquecimento". 
A Muhuraida elaborou um elogio do desenvolvimentismo, ligado às reformas do Estado. O modelo antigo da colonização, pautado na violência e escravização dos indígenas, levou à hostilidade que travou o avanço da sociedade colonial; o modelo pombalino foi defendido como fomento da prosperidade, alcançada por relações cordiais mediadas pelos valores da civilização cristã europeia. Esse é o tema cantado pela lira de Wilkens: o progresso como expansão do comércio e da agricultura, ou seja, como efetiva construção de uma sociedade capitalista colonial.

Compreender a inserção do poema nas contingências históricas do presente de sua produção não significa confiná-lo a um tempo e espaço longínquos. Mesmo porque as forças históricas que estavam em ação no Grão-Pará do século XVIII não se confinam ao passado. Pelo contrário: é vivíssima a ideologia do desenvolvimentismo como eterna promessa de progresso com a exploração da região. Ela continua embasando a imagem que se faz dos povos indígenas como obstáculo ao empreendedorismo capitalista. Não é mistério a intenção da atual presidência e de seu ministro do Meio Ambiente em franquear o acesso à floresta para que o capitalismo explore suas riquezas, livre e desimpedido. Desse modo, defende-se, é preciso “integrar" esses povos, retirá-los de uma "condição bestial”, trazendo-os para os códigos da civilização dita moderna, cujo modelo exemplar de virtudes é a figura do empreendedor burguês. Nesse sentido, não há como não ver que a Muhuraida é um documento do nosso próprio presente.

\section{REFERÊNCIAS}

CALDAS, Y. P. A construção épica da Amazônia no poema Muhuraida, de Henrique João Wilkens. Tese (Doutorado em Literatura Comparada) - FALE, Universidade Federal de Minas Gerais, Belo Horizonte, 2007.

CARDOSO, José Luís; CUNHA, Alexandre Mendes da. Discurso econômico e política colonial no Império Luso-Brasileiro (1750-1808). Tempo - revista do departamento de História da UFF, Niterói, v. 16, n. 31, 2012. Disponível em: https://www.scielo.br/pdf/tem/v17n31/04.pdf. Acesso em out 2019.

Revista Moara, n. 56, vol. 2, jan-jul 2021 ISSN: 0104-0944 
FREIRE, Francisco Joseph. Arte Poética, ou regras da verdadeira poesia. Lisboa: Officina de Francisco Luiz Ameno, 1748. Disponível em: www.archive.org. Acesso em mar 2020.

HANSEN, João Adolfo. Letras coloniais e historiografia literária. Matraga, Rio de Janeiro, n. 18, jan./jun. 2006 Disponível em: http://www.pgletras.uerj.br/matraga/matraga18/matraga18a01.pdf. Acesso em mar 2020.

HANSEN, João Adolfo. Notas sobre o gênero épico. In: TEIXEIRA, Ivan (org.). Épicos: Prosopopeia; O Uraguai; Caramuru; Vila Rica; A Confederação dos Tamoios; I-Juca Pirama. São Paulo: Imprensa Oficial do Estado de São Paulo/Edusp, 2008.

JÚNIOR, José Alves de Souza. Tramas do Cotidiano: religião, política, guerra e negócios no Grão-Pará do setecentos. Belém: Ed.ufpa, 2012.

MAXWELL, Kenneth. Marquês de Pombal - Paradoxo do Iluminismo. 2a. Ed. São Paulo: Paz e Terra, 1996.

MELlO, Francisco de Pina e de. Triumpho da Religião: Poema Épico-Polêmico. Coimbra: Officina de Antonio Simoens Ferreyra, 1756. Disponível em: https://archive.org/details/triumphodareligi00mell/page/n6/mode/2up. Acesso em abr 2020.

MELlo, Francisco de Pina e de. Conquista de Goa, por Affonso de Albuquerque. Coimbra: No Real Colégio das Artes da Companhia de Jesus, 1759. Disponível em: https://archive.org/details/conquistadegoapo00mell/page/n6/mode/2up. Acesso em abr 2020 .

MENDONÇA, Marcos Carneiro de. Amazônia Pombalina - correspondência do Governador e Capitão-General do Estado do Grão-Pará e Maranhão, Francisco Xavier de Mendonça Furtado (Tomo I). 2a . Ed. Brasília: Edições do Senado Federal, 2005.

NOVAES, Fernando. Reformismo ilustrado luso-brasileiro: alguns aspectos. Revista Brasileira de História, São Paulo, n. 7, 1984. Disponível em: https://edisciplinas.usp.br/pluginfile.php/4459734/mod_resource/content/1/NOVAIS\%2 C\%20Fernando.\%20\%E2\%80\%9CO\%20Reformismo\%20Ilustrado\%20lusobrasileiro\%20-\%20alguns\%20aspectos\%E2\%80\%9D.pdf. Acesso em: 09/2019. 
POMBAL, Marquês de. Compêndio Histórico da Universidade de Coimbra. Porto: Campo das Letras, 2008.

PRADO JR., Caio. Formação do Brasil contemporâneo: colônia. São Paulo: Companhia das Letras, 2011.

SILVA, Anazildo Vasconcelos; RAMALHO, Christina Bielinski. Dois momentos da épica árcade-neoclássica brasileira: Vila Rica e Muhuraida. Matraga, Rio de Janeiro, v. 18, n. 29, jul./dez. 2011. Disponível em: https://www.epublicacoes.uerj.br/index.php/matraga/article/view/26058. Acesso em mar 2020.

SILVA, José Manuel Azevedo e. O modelo pombalino de colonização da Amazônia. Revista de História e Sociedade da Cultura, Coimbra, n. 3, 2003. Disponível em: https://www.uc.pt/fluc/iheu/artigos/modelopombalino. Acesso em abr 2019.

TEIXEIRA, Ivan. Mecenato Pombalino e poesia neoclássica - Basílio da Gama e a poética do encômio. São Paulo: Fapesp/edusp, 1999.

TREECE, David. Introdução crítica à Muhuraida. In: WILKENS, Henrique João. Muhuraida ou O Triumfo da Fé - 1785. Manaus: Biblioteca Nacional/UFAM/Governo do Amazonas, 1993.

UOL, "Índio tá evoluindo, cada vez mais é ser humano igual a nós", diz Bolsonaro.

UOL Notícias. São Paulo, 23/01/2020. Política. Disponível em: https://noticias.uol.com.br/politica/ultimas-noticias/2020/01/23/indio-ta-evoluindocada-vez-mais-e-ser-humano-igual-a-nos-diz-bolsonaro.htm. Acesso em abr 2020. UNL (Faculdade de Direito da Universidade Nova de Lisboa). Lei de Boa Razão de 18.08.1769. Disponível em: https://www.fd.unl.pt/Anexos/Investigacao/7599.pdf. Acesso em ago 2019.

WILKENS, Henrique João. Muhuraida ou o Triunfo da Fé. Organização e Compilação por Weberson Fernandes Grizoste. Manaus/Parintins: UEA, 2017. Disponível em: https://www.academia.edu/33114288/MUHURAIDA_OU_O_TRIUNFO_DA_F\%C3\% 89_Henrique_Jo\%C3\%A3o_Wilkens_. Acesso em mar 2020. 